УДК 340

DOI https://doi.org/10.32837/pyuv.v1i4(29).393

\author{
Н. П. Харченко \\ orcid.org/0000-0001-7356-7903 \\ кандидат юридичних наук, \\ старший викладач кафедри теорї держави та права \\ Національної акаделії внутрішніх справ
}

\title{
СТРАТЕГІЧНІ ПРАВОВІ АКТИ УКРАЇНИ: ПЛЮРАЛІЗМ НАУКОВИХ ПІДХОДІВ
}

Теоретико-правове розкриття юридичної природи, понять, змісту, особливостей стратегічних актів у законодавстві України має як наукове, так і практичне значення. Щороку кількість вищезазначених актів зростає. Однак і донині нормативно невизначеними є порядок ухвалення, юридична сила, співвідношення, класифікація, а також відмінність одного стратегічного акта від іншого.

Дана проблема особливо актуальна для України як країни, що націлена на комплексне реформування вітчизняної правової системи в умовах впровадження інновацій у всіх сферах життєдіяльності суспільства та державних інститутах. Будь-які трансформації, а також загалом правова політика держави повинна мати стратегічний та цільовий характер.

Стратегічні акти не були предметом комплексного розгляду вітчизняних дослідників, а розглядалися на рівні кількох статей і тез конференцій [1-4]. Окремі аспекти проблеми були відображені в наукових роботах таких дослідників, як С.С. Алексєєв, Д.Н. Бахрах, С.В. Бобровник, С.Д. Гусарєв, А.М. Завальний, В.Б. Ісаков, В.В. Копєйчиков, А.В. Малько, Н.I. Матузов, П.М. Рабінович, І.О. Соколова, В.Д. Сорокін, О.Д. Тихомиров, Л.В. Томаш, Л.С. Явич.

Метою написання даної наукової статті є вироблення загальнотеоретичної конструкції «стратегічні правові акти" у вітчизняній юридичній доктрині та українській правовій системі.

Задля цього автором були поставлені такі завдання: окреслити наукові позиції щодо визначення поняття «стратегічні акти»; визначити характерні риси стратегічних актів та співвідношення між ними.

Розгляд вітчизняних нормативно-правових актів, що містять у своїй назві слова «доктрина», «концепція», "стратегія», «програма», «план», «основи державної політики» тощо, дозволяє дійти таких висновків. Часто-густо правові акти, які по змісту приписів є стратегіями, мають назву «програма», «концепція», «доктрина» чи «основи державної політики». Навпаки, правові акти, які містять норми нестратегічного характеру, названі стратегіями.

Аналіз вітчизняної та зарубіжної правової доктрини дозволяє дійти висновку, що вагому роль у розробленні цієї проблеми відіграє російська правова наука. Однак, попри грунтовні розвідки у цій сфері, поряд з категорією "стратегічні акти» не менш вживаними є категорії «доктринальні акти», «концептуальні акти», «акти планування» тощо.

Так, I. Маланич пропонує називати такі акти стратегічними нормативними актами. Зокрема, автором дається таке визначення: «Стратегічний нормативний акт - юридичний документ, виданий в порядку правотворчості компетентним органом державної влади, який містить переважно норми, що визначають загальні основи (ідеї), цілі, завдання і принципи розвитку будь-якої сфери правового регулювання суспільних відносин, структурування в порядку перспективного планування [5, с. 118].

Д. Ірошніков і С. Нестеров пропонують об'єднати ці акти шляхом вживання категорії "концептуальні і доктринальні документи" [6, с. 7].

О. Федорченко застосовує категорію «акти програмно-директивного характеру» [7, с. 37], що дещо відповідає тексту одного з проєктів закону Російської Федерації «Про нормативні правові акти в Російській Федерації», де також пропонується категорія "програмні правові акти» та таке нормативне визначення: «<...>програмні правові акти (програми, концепції, стратегії) визначають цілі та завдання розвитку, етапи та способи ї досягнення й рішення, що закріплюють ціннісні орієнтири в діяльності органів державної влади, місцевого самоврядування та організацій, інститутів громадянського суспільства» [8, с. 7]. Виникає питання: чому лише програми, концепції, стратегії є програмними правовими актами. Чи належать доктрини та плани до програмних правових актів?

Поряд з цим законопроєктом не менш цікавим $\epsilon$ інший законопроєкт, який пропонує застосовувати категорію «доктринальні правові акти» та надає таке визначення цього поняття: «<...> спеціальний нормативний правовий акт, спрямований на регулювання цілей, пріоритетів, змісту та способів реалізації державної політики Росії, політики суб'єктів федерації чи муніципальних утворень у різних сферах суспільного, політичного, державного, соціально-економічного 
і культурного розвитку, заснований на системі державного планування і прогнозування на довгострокову, середньострокову та короткострокову перспективу» [8, с. 7]. Та чи може акт регулювати політику? Сутність, зміст та роль будь-якого акта полягає у регулюванні суспільних відносин, у впорядкуванні правового регулювання конкретної сфери суспільних відносин.

Однак запропонована дефініція підтримується А. Кирилових, який також використовує категорію «доктринальний правовий акт» та визначає його як спеціальний нормативний правовий акт, спрямований на регулювання цілей, напрямів, пріоритетів, змісту і способів реалізації державноі політики, політики суб'єктів федерації чи муніципальних утворень у довгостроковій, середньостроковій та короткостроковій перспективі [9, с. 7].

А. Малько та Я. Гайворонська зауважують про своєрідність такої групи документів, як стратегії, концепції, основи, доктрини, та говорять про необхідність створення єдиного лаконічного терміна [8, с. 7]. Саме тому, на їх думку, попри доречність об'єднання таких актів терміном «політико-програмні акти» (чи «акти політико-програмного характеру»), в силу громіздкості цього терміна застосовують все ж таки поняття «доктринальні правові акти». Більш конструктивними є погляди цих науковців щодо некласичності цих актів. Зокрема, вони вказують, що такі акти є нетрадиційними засобами правового регулювання, які містять норми-вказівки, необхідні для формування правової політики в рамках держави, а також мають цільовий і стратегічний характер [8, с. 8].

Цікавою є позиція I. Пляхімовича, який зауважив, що «державні концепції, програми, стратегіï, основні напрями, інші подібні документи утворюють самостійне джерело права, яке може називатися політико-програмним документом» [10, с. 72].

Підтримує цю позицію й М. Мушинський, говорячи, що норми стратегії «мають не чисто юридичний, а й політико-правовий зміст і є засобами вираження (формулювання) правової політики» [11, c. 6].

Ми погоджуємось із позицією I. Берназюк, яка акцентує увагу на тому, що «стратегічні акти є документами особливого виду, які істотно відрізняються за змістом, а іноді і за формою від нормативно-правових» [4, с. 154].

Не менш гострою є дискусія науковців щодо природи стратегічних актів, а саме щодо того, $є$ вони правовими чи ні. Прихильники неправової природи стратегічних актів аргументують свою позицію відсутністю настання юридичних наслідків, адже норми таких актів не впливають на виникнення суб'єктивних прав, юридичних обов'язків, юридичної відповідальності, а також на виникнення, зміну чи припинення правовідносин.
Попри те, що стратегічні акти не впливають на виникнення суб'єктивних прав, не накладають юридичних обов'язків, не визначають заходів юридичної відповідальності, не змінюють правового статусу суб'єктів і не є підставою для виникнення, зміни або припинення правовідносин, все ж таки вони ухвалюються відповідно до законодавства і на підставі тих норм і принципів правотворчості, які використовуються при прийнятті усіх нормативно-правових актів, а також в межах компетенції суб'єктів правотворчості, зокрема і вищих органів державної влади. Отже, такі акти проходять всі стадії правотворчості згідно з усталеними правилами. Крім того, ці акти застосовуються не лише у вітчизняному законодавстві, а й у правових системах зарубіжних країн. Згідно зі статистичними даними ухвалення стратегічних актів щорічно збільшується.

Дійсно, стратегічні акти - це нетипові правові акти, які не містять норм-приписів у традиційному розумінні. Характерною рисою таких актів $€$ наявність норм-принципів, норм-цілей тощо, тобто норм, що закріплюють перспективні цілі i завдання правового регулювання якої-небудь сфери, формулюють спектр проблем у цій галузі, а також основні напрями діяльності та заходи, необхідні для вирішення цих проблем. Як правило, такі акти є базисом, фундаментом для ухвалення інших класичних та некласичних нормативно-правових актів.

Аналіз вітчизняного законодавства дозволяє дійти висновку, що стратегічні правові акти мають всі ознаки, що притаманні нормативно-правовим актам. Однак вони також мають і певні особливості, що зумовлюють їх особливу юридичну природу та зміст. Так, серед специфічних ознак (характеристик) стратегічних правових актів, що відрізняють їх від інших нормативно-правових актів, слід виокремити:

- спеціальне найменування (доктрина, концепція, стратегія, програма, план, основи державної політики тощо);

- домінування норм-ідей, норм-цілей, нормзавдань, норм-принципів тощо, тобто декларативних, розпорядчих норм;

- наявність як правових норм, так і доктринальних, концептуальних положень, системи заходів і механізмів реалізації, а також критеріїв оцінки ефективності;

- вони спрямовані, як правило, на впорядкування не конкретних галузей законодавства, а міжгалузевих правових інститутів;

- вони мають комплексний об’єкт регулювання;

- їня реалізація неможлива без міжсистемних зв' язків правовідносин в різних сферах суспільного життя (навіть якщо ці акти не містять відповідних галузевих правових норм) [8, с. 9];

- вони є основою для ухвалення інших правових актів; 
- їня юридична сила є різноманітною, адже вони ухвалюються різними державними органами, тому можуть мати як законний, так і підзаконний характер;

- вони здебільшого ухвалюються на визначений строк.

Що стосується визначення поняття та адекватної категорії, то вважаємо, що доречнішим є застосування категорії «стратегічні правові акти», адже усі ці акти містять приписи, що визначають систему офіційних концептуальних ідей і поглядів, науково обгрунтованих принципів, єдиних організаційних вимог, а також напрямів, пріоритетів, способів, суб'єктів реалізації державної політики щодо впорядкування юридично однорідних суспільних відносин в різних сферах у чітко визначений проміжок часу.

Отже, стратегічні акти «доктрина», «основи державної політики<...>» або «концепція» визначають загальні погляди і принципи, головні ідеї розв'язання тих чи інших правових проблем, а акти «стратегія», «програма», «план дій» містять норми, в яких конкретизуються і визначаються конкретні кроки, суб'єкти реалізації, а також моніторинг ефективності того чи іншого шляху. Здебільшого останні мають динамічніший характер та ухвалюються на певний період. Вони, як правило, мають менш довгостроковий характер, ніж концепція чи доктрина.

Отже, з огляду на зазначене під стратегічними актами слід розуміти сукупність письмових правових актів, виданих в порядку правотворчості компетентним органом державної влади, які містять норми, що визначають концептуальні ідеї, погляди, основи, конкретні заходи, засоби, напрями та механізми правового регулювання суспільних відносин у конкретній сфері.

Правова природа, юридична сила і ступінь обов'язковості стратегічних актів нормативно не визначені. Ці акти мають неоднозначну юридичну силу залежно від правотворчого суб'єкта, що затвердив той чи інший стратегічний акт. Беручи до уваги важливість цих актів у підвищенні ефективності правового регулювання суспільних відносин, а також наявність позитивного досвіду використання їх в загальносвітовій правовій практиці, вважаємо за необхідне провести систематизацію наукових поглядів і юридичної практики шляхом закріплення їх місця і правової природи в законодавстві України, а саме в спеціальному законі про нормативно-правові акти [12, с. 94].

\section{Jimepamypa}

1. Харченко Н.П. Особливості стратегії як нормативно-правового акта України. Пріоритетні напрялки розвитку правової систели України : матеріали Міжнар. наук.-практ. конф., м. Львів, 24-25 січня 2020 р. Львів, 2020. С. 111-114.
2. Харченко Н.П. Стратегічні акти в законодавстві України. Держава і право в Уловах глобалізації: ре алії та перспективи : матеріали Міжнар. наук.-практ. конф., м. Дніпро, 31 січня - 1 лютого 2020 р. Дніпро, 2020. C. 121-124.

3. Харченко Н.П. Стратегия как вид нормативноправового акта. Legea Se Viata. 2019. № 11 (305). C. $125-128$.

4. Берназюк И. Стратегічні акти Верховної Ради України: поняття, види та особливості. Підприєлство, господарство і право. 2017. № 1. С. 153-158.

5. Маланыч И.Н. Понятие стратегического нормативного акта как результата эволюции системы законодательства России. Юридические записки Воронежского государственного университета. 2009. № 22. С. $117-130$.

6. Ирошников Д.В., Нестеров С.В. Понятие и классификация концептуальных и доктринальных документов Российской Федерации. Правовая инициатива. 2013. № 7. С. 7-13.

7. Федорченко А.А. Концептуальное право: источник стратегического правового регулирования. Ученые труды Российской акаделии адвокатуры и ноmapuama. 2016. № 3. С. 37-43.

8. Малько А.В., Гайворонская Я.В. Доктринальные акты как основной инструмент правовой политики. Право. Журнал Высшей школы эконолики. 2018. № 1. С. 4-25.

9. Кирилловых А.А. Правовая доктрина и доктринальность в праве: к вопросу об источниках правового регулирования. Законодательство и эконолика. 2015. № 8. С. $29-41$.

10. Пляхимович И.И. Юридическая природа концепций совершенствования законодательства и иных политико-программных документов. Веснік Канстітуиійнага Суда Рэспублікі Беларусь. 2009. № 2. C. 71-81.

11. Мушинский М.А. Стратегии, концепции, доктрины в правовой системе Российской Федерации: проблемы статуса, юридической техники и соотношения друг с другом. Юридическая техника. 2015. № 9. С. 488-499.

12. Харченко Н.П. Стратегические акты Украины: понятие и особенности. Legea Se Viata. 2020. № 3 (339). C. 89-94.

\section{Анотація}

Харченко Н. П. Стратегічні правові акти України: плюралізм наукових підходів. - Стаття.

У статті здійснюється теоретико-правове розкриття юридичної природи, понять, змісту, особливостей стратегічних правових актів у законодавстві України шляхом аналізу різних наукових позицій. Констатується, що, оскільки й донині нормативно невизначеними $€$ порядок ухвалення, юридична сила, співвідношення, а також відмінність одного стратегічного акта від іншого, часто-густо правові акти, які за змістом приписів є стратегіями, мають назву "програма», «концепція», «доктрина» чи «основи державної політики». Навпаки, правові акти, які містять норми нестратегічного характеру, названі стратегіями. Виокремлюється низка специфічних ознак (характеристик) стратегічних правових актів, що вирізняють їх від інших нормативно-правових актів. Зокрема, це такі ознаки: спеціальне найменування (доктрина, концепція, стратегія, програма, план, основи державної політики тощо); домінування у змісті норм-ідей, норм-цілей, норм-завдань, норм-принципів тощо, тобто декларативних, розпорядчих норм; наявність як правових норм, так і доктри- 
нальних, концептуальних положень, системи заходів і механізмів реалізації, а також критеріїв оцінки ефективності; спрямованість на впорядкування не конкретних галузей законодавства, а міжгалузевих правових інститутів; наявність комплексного об'єкта регулювання; їх реалізація неможлива без міжсистемних зв'язків правовідносин в різних сферах суспільного життя (навіть якщо ці акти не містять відповідних галузевих правових норм); вони є основою для ухвалення інших правових актів; їхня юридична сила є різноманітною, адже вони ухвалюються різними державними органами, тому можуть мати як законний, так і підзаконний характер; вони здебільшого ухвалюються на визначений строк. Аргументується доречність застосування категорії «стратегічні правові акти» як категорії, що охоплює всі нетипові правові акти стратегічного характеру, в яких містяться приписи, що визначають систему офіційних концептуальних ідей і поглядів, науково обгрунтованих принципів, єдиних організаційних вимог, а також напрямів, пріоритетів, способів, суб'єктів реалізації державної політики щодо впорядкування юридично однорідних суспільних відносин в різних сферах у чітко визначений проміжок часу.

Ключові слова: стратегічні акти, стратегія, доктрина, концепція, основи державної політики.

\section{Summary}

Kharchenko N.P. Strategic legal acts of Ukraine: pluralism of scientific approaches. - Article.

The article deals with the theoretical and legal disclosure of the legal nature, concept, content, features of strategic legal acts in the legislation of Ukraine by analyzing various scientific positions. It is stated that since to this day the procedure of adoption, legal force, correlation, as well as the difference between one strategic act and another are often vaguely defined, often legal acts, which in terms of prescriptions are strategies, are called "program", "concept", "Doctrine" or "foundations of public policy"; and vice versa: legal acts that contain non-strategic rules are referred to as "strategies". A number of specific features (characteristics) of strategic legal acts are distinguished, which distinguish them from other normative legal acts: special name (doctrine, concept, strategy, program, plan, foundations of state policy, etc.); dominance in the content of normsideas, norms-goals, norms-tasks, norms-principles, etc., ie declarative, regulatory norms; the availability of both legal and doctrinal conceptual provisions, a system of measures and a mechanism for implementation, as well as performance evaluation criteria; focus on regulating not specific branches of legislation but inter-sectoral legal institutions; presence of a complex object of regulation; their realization is impossible without interconnections of legal relations in different spheres of public life (even if these acts do not contain relevant sectoral legal norms); is the basis for the adoption of other legal acts; the legal force is diverse, since it is adopted by different state bodies and can therefore have both legal and by-law character; for the most part, they are approved for a fixed period. The expediency of applying the category "strategic legal acts" as a category, encompassing all atypical legal acts of a strategic nature, which contain prescriptions defining a system of official conceptual ideas and views, scientifically substantiated principles, common organizational requirements, as well as directions, priorities, ways, the subjects of the implementation of state policy on the ordering of legally homogeneous social relations in different spheres in a clearly defined period of time.

Key words: strategic acts, strategy, doctrine, concept, foundations of states policy. 